doi: http://dx.doi.org/10.5892/ruvrv.2012.101.234245

\title{
A produção de insulina artificial através da tecnologia do DNA recombinante para o tratamento de diabetes mellitus
}

\author{
Drielle Silva Andrade LOPES ${ }^{1}$ \\ Mitsuê Hamada Nery PESSOA ${ }^{2}$ \\ Rodrigo da Silva SANTOS ${ }^{3}$ \\ Mônica Santiago BARBOSA ${ }^{4}$
}

1 - Bióloga. Departamento de Biologia do Centro Universitário de Goiás (Uni-ANHANGUERA).

2 - Bióloga. Departamento de Biologia do Centro Universitário de Goiás (Uni-ANHANGUERA).

3 - Professor Colaborador. Departamento de Bioquímica e Biologia Molecular do Instituto de Ciências Biológicas da Universidade Federal de Goiás.

4 - Professora Orientadora. Departamento de Biologia do Centro Universitário de Goiás (Uni-ANHANGUERA) e Departamento de Ciências Biológicas e da Saúde, Universidade Federal de Goiás, Campus Jataí-GO.

E-mail: santiagosant@gmail.com (Barbosa, MS).

Resumo: A Engenharia Genética proporcionou avanços na área médica e na indústria farmacêutica, com a criação da Tecnologia do DNA recombinante (DNA formado pela união de genes de organismos diferentes, resultando da combinação de diferentes seqüências de DNAs). Essa tecnologia é utilizada na produção de insulina artificial que é obtida através da bactéria Escherichia coli, sendo geneticamente modificada e capaz de sintetizar o hormônio. A insulina é o principal meio utilizado no tratamento do Diabetes Mellitus (DM), uma doença crônica que ocorre quando o pâncreas não produz insulina suficiente ou quando o corpo não utiliza eficazmente a insulina produzida. Com essa tecnologia a insulina artificial é produzida em menor tempo e em maior escala, beneficiando os portadores do DM, para que dessa forma possam levar uma vida normal.

Palavras-Chave: Engenharia genética, clonagem molecular, tecnologia do DNA recombinante, insulina artificial, diabetes mellitus.

\section{The artificial production of insulin by recombinant DNA technology for the treatment of diabetes mellitus}

\begin{abstract}
Genetic Engineering has provided advances in medicine and the pharmaceutical industry with the creation of recombinant DNA technology (DNA from the combination of different sequences of DNAs belonging different organisms). For example, this technology is used in the production of artificial insulin through the bacterium Escherichia coli, that is genetically modified so that there is capable of synthesizing this hormone. The application of insulin is the primary method used in the treatment of patients with Diabetes mellitus (DM), a chronic disease that occurs when the pancreas does not produce enough insulin or when the body does not effectively use the insulin produced. With this technology in artificial insulin is produced in less time and on a larger scale, will benefit people with diabetes, so this way can lead a normal life.
\end{abstract}

Keywords: Genetic engineering, molecular cloning, recombinant DNA technology, artificial insulin, diabetes mellitus. 


\section{Introdução}

A Engenharia Genética é o conjunto de processos que permitem a manipulação do genoma de organismos vivos, com a consequente alteração das habilidades de cada espécie. Esta possibilidade de alteração das potencialidades genéticas dos organismos resultou na colaboração íntima e constante entre a chamada ciência básica e a ciência aplicada. São em grande número os objetivos práticos da pesquisa biológica, desde a satisfação da curiosidade humana sobre a natureza da vida, até o controle e eliminação de doenças humanas, de outros animais e de plantas, enfim, a melhoria da qualidade de vida. A Tecnologia do DNA recombinante proporciona a produção de insulina artificial ou recombinante, trazendo enorme avanço na área da medicina e consequentemente na área industrial. Mesmo existindo ainda alguns limites (ética, preconceito, falta de informação e alto custo) para a aplicação prática da Engenharia Genética, não restam dúvidas de que a ciência dispõe de alta e promissora tecnologia para a solução de problemas que antes pareciam não ter solução (Candeias, 1991).

A insulina humana é um hormônio peptídico e protéico, produzido nas células pancreáticas localizadas nas Ilhotas de Langerhans, que tem como função a redução da glicemia (taxa de glicose no sangue). A deficiência na secreção ou na ação da insulina produz uma doença chamada Diabetes
Mellitus (DM), que causa profundas anormalidades no organismo afetado (Lima, 2001). Sendo assim, demonstraremos nesse estudo a importância dessa nova tecnologia aplicada na produção de insulina artificial e os benefícios que ela traz ao tratamento do DM.

\section{Diabetes Mellitus (DM): Aspectos Gerais e Tratamento}

É uma doença provocada pela deficiência de produção e/ou ação da insulina, que causa sintomas agudos e complicações crônicas características. $\mathrm{O}$ distúrbio envolve o metabolismo da glicose, das gorduras e das proteínas e tem graves consequências tanto quanto surge rapidamente como quando se instala lentamente. Apresenta diversas formas clínicas, sendo classificada em: DM1 (ocasionada pela destruição das células betas do pâncreas, em geral por decorrência de doença auto-imune, levando a deficiência absoluta de insulina), DM2 (provocada predominantemente por um estado de resistência à ação da insulina associado a uma relativa deficiência de sua secreção), Diabetes Gestacional (quando a doença é diagnosticada durante a gestação, em pacientes sem aumento prévio da glicose) e DM associadas a desordens genéticas, infecções, doenças pancreáticas, uso de medicamentos, drogas ou outras doenças endócrinas (Czepielewski, 2006).

$\mathrm{O}$ pH do plasma sanguíneo de pessoas diabéticas é frequentemente menor que o valor normal $(7,4)$ condição esta chamada de 
acidose. É causada pela superprodução de ácidos metabólicos e o $\mathrm{pH}$ do sangue pode cair a 6,8 ou abaixo, levando a lesões irreparáveis nos tecidos, e à morte. Esse aumento da acidez é um indicativo de alterações profundas no balanço ácido-base do organismo. A acidez aumentada é devido à extensa formação de corpos cetônicos no fígado e à sua liberação no sangue. Como os tecidos não conseguem utilizar a glicose sanguínea, o fígado tenta compensar essa deficiência aumentando a utilização dos ácidos graxos como combustível, mas isso provoca a superprodução de corpos cetônicos, além da capacidade dos tecidos em oxidá-los (Lima, 2001). Assim como também descrito por Lima (2001), a administração de insulina para corrigir a deficiência endócrina e a administração de bicarbonato de sódio como da capacidade do tampão bicarbonato, podem trazer toda a química do organismo de volta para um balanço quase normal dentro de 12 a 24 horas.

Os sintomas do DM são decorrentes do aumento da glicemia e das complicações crônicas que se desenvolvem em longo prazo. Esses sintomas são: sede excessiva, aumento do volume da urina, aumento do número de micções, fadiga, fraqueza, tonturas, visão embaçada, aumento de apetite e perda de peso. Estes sintomas tendem a se agravar progressivamente e podem levar a complicações severas que envolvem queixas visuais, cardíacas, circulatórias, digestivas, renais, urinárias, neurológicas, dermatológicas e ortopédicas. O diagnóstico pode ser presumido em pacientes que já apresentam os sintomas e sinais clássicos da doença, o diagnóstico laboratorial é estabelecido pela medida da glicemia no soro ou plasma sanguíneo, após um jejum de 8 a 12 horas. Os grupos que são mais propícios a terem essa doença são as crianças, pessoas obesas e sedentárias, certos grupos étnicos, pessoas com histórico de diabetes na família e mulheres que tiveram diabetes gestacional (Czepielewski, 2006).

O DM não tem cura, exceto pelo transplante de pâncreas, os objetivos do tratamento são dirigidos para se obter uma glicemia normal e controlar as alterações metabólicas associadas, sendo diferente para cada paciente. Envolve quatro aspectos importantes: plano alimentar com uma dieta adequada e balanceada, atividades físicas, medicamentos com acompanhamento profissional especializado (Czepielewski, 2006).

O DM é considerado um sério problema de saúde pública no mundo todo, em função, do crescente número de pessoas atingidas, pela complexidade que constitui o processo de viver com essa doença, falta de acesso e condições de obtenção do tratamento e alta taxa de mortalidade resultante da doença. As prospecções apontam que cerca de $8 \%$ da população brasileira tem o diagnóstico de diabetes (Francioni \& Silva, 2007). Estima-se que a doença aumentará na população mundial, devido à transição 
demográfica de $2,8 \%$ para $4,4 \%$, entre os anos de 2000 e 2030 (Rosa, 2007).

A prioridade no tratamento do DM é devolver ao paciente seu equilíbrio metabólico e mantê-lo assim, propiciando um estado o mais próximo possível da fisiologia normal do organismo, o que não é tarefa fácil. Isto implica em conscientizar paciente $\mathrm{e}$ família sobre o significado do bom controle metabólico, conduzindo-o também a um bem estar físico, psíquico e social (Dib, 2006).

O conceito de tratamento intensivo do DM não se prende ao número de doses de insulina que devem ser tomadas. Seu princípio consiste em modificações no esquema terapêutico, de acordo com os resultados da auto-monitorização glicêmica. A factibilidade do tratamento intensivo do DM implica em alguns pressupostos. Em primeiro lugar estão o desejo e a motivação do paciente para realizá-lo. Em segundo, a capacitação e a habilitação do médico e da equipe multiprofissional que cuida do paciente. Outra condição básica é que a automonitorização da glicemia também seja intensiva, assim como a comunicação entre o paciente e a equipe de saúde. O problema do custo ou acesso à auto-monitorização também pode ser encarado como uma barreira ao tratamento intensivo. Todo tratamento impõe limites, no caso do tratamento intensivo a incidência de hipoglicemia é considerada como o mais importante limite, que varia de paciente para paciente. Outra limitação importante é o aumento de peso, grupos de pacientes com tratamento intensivo ganham mais peso que grupos tratados com esquemas convencionais. Embora este aumento de peso implique em ganho de massa magra, ele tem certamente contribuído para o aumento da prevalência da obesidade nos pacientes (Dib, 2006).

Uma maneira de evitar um risco de uma hipoglicemia com o uso da insulina humana regular é recomendar sua aplicação entre 30 e 45 minutos antes da refeição. Com o auxílio da tecnologia do rDNA procurou-se desenvolver uma insulina que tivesse um comportamento semelhante ao da insulina produzida naturalmente pelo organismo. Causando um início mais rápido e uma duração mais curta do que a insulina regular (Coelho, 1997).

Um dos principais problemas encontrados era que as moléculas de insulina humana, quando muito próximas, têm a tendência de se auto-associarem, formando assim, um dímero. Foi necessário então, buscar uma molécula de insulina que tivesse uma tendência reduzida de auto-associação, e consequentemente, uma maior capacidade de se dissociar de hexâmetro (forma inicial) em dímeros, e posteriormente em monômeros, estruturas individuais que são absorvidas pelos capilares sanguíneos. Isso foi conseguido invertendo-se as posições dos aminoácidos prolina e lisina, que na cadeia da insulina humana ocupam, respectivamente, as posições 28 e 29 . O resultado foi justamente a insulina lispro, que possui uma conformação 
molecular, semelhante à insulina humana e um perfil de tempo de ação também mais próximo ao fisiológico do que a insulina regular. A insulina lispro pode ser administrada até 15 minutos antes das refeições, o que facilita bastante a vida das pessoas que necessitam de insulina (Coelho, 1997).

Devido à seriedade desse problema e com o auxilio da tecnologia do DNA recombinante é possível obter organismos com características novas ou não encontradas na natureza, que permitem uma moderna alternativa para o melhoramento genético de espécies de valores biotecnológicos, abrindo a perspectiva de produção de polipeptídios de interesse, que nesse caso é a insulina (Lima, 2001). Esse novo método proporciona a produção de insulina artificial em tempo reduzido, geralmente 30 dias, se comparado ao método tradicional que utiliza como matéria prima o pâncreas de mamíferos, preferencialmente o suíno ou bovino.

\section{A Tecnologia do DNA recombinante (rDNA)}

Moléculas de DNA artificial contendo segmentos covalentemente ligados, derivados de duas ou mais fontes, são chamados de DNAs recombinantes (Lehninger, 2011). A Tecnologia do rDNA envolve modificação direta do DNA, de forma a alterar características do organismo vivo ou introduzir novas características. $\mathrm{O}$ isolamento dos genes de interesse é conduzido por meio de técnicas de clonagem molecular que consistem em induzir um organismo vivo a amplificar a sequência de DNA de interesse, em sistemas que permitem uma fácil purificação e recuperação do referido fragmento de DNA. Para isso, são utilizados vetores de clonagem, nos quais a sequência de DNA de interesse é inserida, utilizando a enzima DNA ligase. Quando necessário, o fragmento de DNA de interesse pode ser libertado do vetor por meio de enzimas de restrição. Uma vez isolado o gene de interesse, estes fragmentos de DNA são incorporados no genoma do organismo alvo, resultando em um organismo geneticamente modificado, cuja característica adquirida passa a ser hereditária (Ferraz, 2007).

A clonagem do DNA envolve a separação de um gene específico e sua ligação a uma molécula de DNA transportadora e depois a replicação deste DNA modificado, o resultado é uma amplificação seletiva de um gene particular. A bactéria Escherichia coli foi o primeiro organismo usado para o trabalho do rDNA e ainda é a célula hospedeira mais comum (Lehninger, 2011).

A clonagem de um segmento de DNA acarreta cinco procedimentos gerais: cortar o DNA no local preciso (enzimas de restrição), unir dois fragmentos de DNA covalentes (DNA ligase), selecionar uma pequena molécula de DNA capaz de auto-replicação (vetores de clonagem), um método para transferir o DNA recombinante para uma célula hospedeira e selecionar as células 
hospedeiras que contenham o DNA recombinante. Os métodos usados para realizar estas tarefas e outras relacionadas são conhecidos como Tecnologia do DNA recombinante (Nardi, 2002; Lehninger, 2011).

Muito importante para a tecnologia do rDNA são as enzimas, usadas para fragmentar o DNA deixando extremidades de fitas simples de DNA que permitem a ligação dos fragmentos. Assim, o DNA bacteriano pode recombinar com DNA humano ou de qualquer outra espécie, abrindo a possibilidade de clonar genes humanos ou isolar proteínas de culturas bacterianas. Uma importante consequência da especificidade destas enzimas de restrição é que o número de clivagens feito por cada uma delas no DNA de qualquer organismo é definido e permite o isolamento de fragmentos deste DNA (Rodrigues et al, 2003).

Pequenas diferenças entre moléculas de DNA relacionadas são rapidamente detectadas, porque seus fragmentos de restrição podem ser separados e visualizados através de eletroforese em gel. Em muitos tipos de géis, a mobilidade eletroforética de um fragmento de DNA é inversamente proporcional ao número de pares de bases, até certo limite. Géis de poliacrilamida são utilizados para separar fragmentos contendo até 1.000 pares de bases, enquanto géis mais porosos, feitos com agarose, são utilizados para resolver misturas de fragmentos de tamanhos maiores. Uma característica importante desses géis é o alto poder de resolução. Em certos tipos de géis, fragmentos de até centenas de nucleotídeos de comprimento diferindo em apenas um nucleotídeo podem ser distinguidos. O gel pode ser corado com brometo de etídeo, um composto que, quando ligado a uma molécula de DNA e submetido à luz UV, emite uma fluorescência de cor laranja (Zaha, 2003).

Para a clonagem de um determinado segmento de DNA, as enzimas de restrição mais utilizadas são aquelas que geram fragmentos com extremidades de fita simples complementares de até quatro nucleotídeos de comprimento, denominadas extremidades coesivas. Fragmentos de DNA contendo extremidades coesivas complementares podem ser unidos pela DNA ligase, que catalisa a formação de uma ligação fosfodiéster entre as duas moléculas. DNA ligase requer um agrupamento $\mathrm{OH}$ livre na extremidade 3' de uma das cadeias de DNA e um agrupamento fosfato na extremidade $5^{\prime}$ da outra cadeia (Rodrigues et al, 2003; Zaha, 2003).

Existem, também, certas endonucleases de restrição que cortam a molécula de DNA sem criar extremidades coesivas. Essas moléculas de DNA com extremidades cegas podem ser ligadas a vetores que também possuam extremidades cegas pela DNA ligase. A presença de extremidades coesivas, no entanto, aumenta a eficiência da ligação e, por isso, extremidades cegas podem ser convertidas em extremidades coesivas, pela adição de um excesso de 
oligonucleotídeo linker (molécula de DNA de fita dupla, com cerca de 10 a 12 nucleotídeos de comprimento, cuja sequência contém um sítio de clivagem para uma ou mais enzimas de restrição) (Zaha, 2003).

Após o isolamento de uma informação genética, por exemplo, um fragmento de DNA obtido pela clivagem com enzimas de restrição, poderá ser inserido numa outra molécula de DNA diferente, capaz de amplificar aquela informação genética em centenas de cópias. Este processo de amplificação é obtido através do uso de moléculas de DNA que são os chamados vetores de clonagem molecular (Rodrigues, 2003).

Esses vetores é que transportam o inserto de DNA para dentro da célula hospedeira, onde ele poderá ser replicado. A molécula de rDNA é introduzida dentro de uma célula hospedeira apropriada. $\mathrm{O}$ processo de introdução de DNA em células é chamado de transformação (Zaha, 2003).

A célula hospedeira contendo uma única molécula de rDNA, divide-se várias vezes, formando uma colônia de células derivadas da célula hospedeira original. Cada célula da colônia possui, ao menos, uma cópia da molécula recombinante. Essas células são chamadas de transformantes ou células transformadas. Tais transformantes são, normalmente, distinguidos das células que não receberam a molécula de DNA recombinante pela presença de um gene marcador, presente no DNA do vetor de clonagem (Zaha, 2003).

Todos os vetores de clonagem devem conter sequências que permitam a sua replicação autônoma dentro da célula hospedeira, além disso, os vetores mais úteis possuem pelo menos um sítio único de clonagem, que é um sitio de restrição que não se repete na molécula, permitindo a inserção sítio-específica de uma outra molécula de DNA. Alguns vetores contêm sítios únicos para várias endonucleases de restrição posicionados lado a lado, em um segmento denominado de sítio múltiplo de clonagem (Zaha, 2003).

Três tipos de vetores de clonagem são mais usados em E. coli: plasmídios, bacteriófagos e cosmídios. Os plasmídios são moléculas de DNA circulares que se replicam separadamente do cromossomo hospedeiro, ocorrem naturalmente e variam de tamanho de 5.000 a 400.000 pares de bases. Eles podem ser introduzidos nas células bacterianas pelo processo de transformação. Algumas características importantes de um vetor de clonagem são: a origem de replicação, genes que confiram resistência a antibióticos e sítios de restrição. Depois desses processos o vetor recombinante é introduzido numa célula hospedeira que o clona, à medida que a célula realiza muitas gerações de divisões celulares. Clonar um gene é a primeira etapa de um planejamento muito maior. Um gene clonado pode ser usado para gerar grandes quantidades do seu 
produto protéico, sendo o produto de interesse

primário. A compreensão dos fundamentos do metabolismo do DNA, RNA e proteína na $E$. coli tornou possível expressar genes clonados para estudo de seus produtos protéicos (Nardi, 2002; Lehninger, 2011).

\section{Aplicações da Engenharia Genética na produção de insulina}

O sofrimento decorrente das múltiplas injeções de insulina diárias a que são submetidos os pacientes com DM tem sido um estímulo para a busca de alternativas substitutas, principalmente as que exerçam seus efeitos por via oral. Algumas dessas alternativas são pequenas moléculas que, de uma forma ou de outra, mimetizam a ação da insulina em pacientes diabéticos (Filho, 2003).

A tecnologia do rDNA permitiu a expressão de proteínas heterólogas em microrganismos e células hospedeiras, como a E. coli. A insulina artificial ou recombinante foi o primeiro produto da tecnologia do rDNA comercializado mundialmente. A construção do gene sintético para a pró-insulina humana foi iniciada a partir da sequência de aminoácidos dessa proteína. Utilizando - se os códons genéticos para E. coli para uma melhor expressão do gene nessa bactéria, foi montado um gene codificando a proteína humana. Esse gene contém 18,6\% de bases de códons substituídas, porém nenhuma das modificações feitas nos códons alterou o aminoácido de correspondência (Lima, 2001).
O gene da pró-insulina humana foi clonado em um vetor para realização do sequenciamento de DNA e a confirmação da sequência nucleotídica correta do gene e posteriormente subclonado no vetor de expressão e o plasmídio foi utilizado para transformação. A célula transformada deve ser submetida às condições que facilitem a expressão do rDNA, resultando em grandes quantidades de insulina, que antes de serem comercializadas deverão passar pelo processo de purificação (Lima, 2001). A insulina produzida pela tecnologia do DNA recombinante apresenta a vantagem de eliminar a possibilidade de contaminantes ou agentes infecciosos que podem estar presentes nas proteínas purificadas de animais. Uma das maiores expectativas neste campo é a possibilidade de se obter mutantes com atividade muito superior ao da proteína nativa e sem certos efeitos adversos. A determinação e caracterização da estrutura de proteínas ganham maior impacto pela possibilidade de expressão/purificação de proteína recombinante em larga escala (Rodrigues et al, 2003).

No ano de 2007 em Buenos Aires, Argentina foi anunciado o nascimento de quatro vacas transgênicas, da Raça Jersey, com o gene humano para a produção de insulina no leite. A pretensão dos cientistas responsáveis pelo feito é a diminuição dos custos da insulina no mercado em pelo menos $30 \%$. A produção do leite pelas vacas transgênicas é uma etapa intermediária na 
elaboração de insulina artificial, a qual posteriormente deverá ser isolada e purificada para produção em escala industrial. Os cientistas afirmam que seriam necessárias apenas vinte e cinco vacas produtoras de insulina para dar resposta à necessidade dos 1,5 milhões de argentinos diabéticos (Ferraz, 2007).

Até bem pouco tempo atrás, a Genética Molecular de plantas também era um área totalmente inexplorada. Isso se devia, em parte, às dificuldades em se trabalhar com as plantas de maior interesse econômico. Essas possuem genomas complexos e grandes, devido à poliploidia (algumas com pelo menos quatro cópias para cada cromossomo), o que dificultava muito a identificação de mutações recessivas e a manipulação do DNA (Zaha, 2003).

Aos poucos os pesquisadores foram aprendendo a manipular e a selecionar as plantas que mais se prestavam às manipulações genéticas e hoje em dia, grandes progressos estão sendo obtidos, principalmente na área de geração de linhagens que apresentam genes exógenos sendo expressos em seus genomas e que conferem vantagens, seja para a planta ou para o homem. O domínio da tecnologia que permite a modificação genética de plantas e de qualquer outro organismo de maneira geral está possibilitando avanços incríveis. Aos organismos que sofreram algum tipo de manipulação genética dá-se o nome de organismos geneticamente modificados ou transgênicos (Zaha, 2003).

No caso da produção de insulina recombinante, atualmente estão sendo utilizadas espécies como alface, batata, feijão e o tabaco. Os vegetais produzem proteínas recombinantes equivalentes à sua forma nativa, com pouco investimento de capital inicial e resultando em produtos seguros para o consumidor. Como não há possibilidade de contaminação, o uso de plantas evita gastos com purificação de potenciais organismos causadores de doenças em humanos. Além disso, as substâncias recombinantes de origem vegetal têm demonstrado estabilidade, oferecendo vantagens de estocagem e transporte. De acordo com os estudos, a expressão das proteínas permanece estável em temperatura ambiente, sem nenhuma perda de atividade. Por todas essas características, a expectativa é de que cheguem ao menor preço possível às mãos de médicos e farmacêuticos (Rech, 2004).

Cápsulas de insulina produzidas em alface geneticamente modificada podem ser a chave para restaurar a habilidade do corpo em produzir insulina e ajudar milhões de pessoas que sofrem de diabete dependente de insulina. A insulina seria administrada aos pacientes como um pó em cápsulas porque a dosagem deve ser devidamente controlada com cuidado por especialistas da área (Daniell, 2007). O processo de produção de insulina através da alface é feito da seguinte maneira: o gene da insulina humana é selecionado; esse gene é 
introduzido na folha de alface; a folha de alface passa a expressar o antígeno que se deseja para combater o DM; depois de colhido, o alimento plantado sob rígido controle em uma casa de vegetação, pode ser seco, transformado em pó para venda e consumo (Rech, 2004).

A descoberta de uma proteína com características da insulina bovina ocorreu durante investigações sobre o efeito de proteínas do tegumento de sementes de feijão na sobrevivência do caruncho. Essa proteína tem massa molecular idêntica e sequência primária exatamente igual à da insulina bovina. Além disso, a proteína isolada reage com anticorpos antiinsulina (humana) da mesma maneira que a insulina bovina. No que sugere a presença de insulina em plantas, parece haver um paradigma que estabelece que as plantas não se valem de hormônios peptídicos, como a insulina, para seus processos metabólicos. Há consequentemente, descrença de que os vegetais possam se valer de insulina, por exemplo, para o controle da metabolização de açúcar em suas células. Há interesse em se utilizar plantas como produtoras de proteínas animais de difícil preparação ou daquelas requeridas em grandes quantidades, a preços acessíveis (Filho 2003).

As vagens verdes de feijões são recomendadas como sendo úteis no tratamento do diabetes, a insulina isolada das mesmas tem os mesmos efeitos que a animal na redução dos níveis de glicose. Vagens são utilizadas para a preparação de chás ou consumidas como saladas. Além de evidenciada a presença de insulina em vagens e tegumentos de sementes de feijão em formação, também há presença nas folhas dessa leguminosa. Alguns exemplos de plantas que podem ser utilizadas na produção de insulina artificial e que também podem ser consumidas no tratamento de diabetes: feijãode-porco (Canavalia ensiformis), feijão-deboi (Canavalia braziliensis), feijão-de-corda (Vigna unguiculata) e as folhas de pata-devaca (Bauhinia forficata). Na preparação de insulinas de plantas elas são cromatografadas em colunas de troca iônica e de filtração molecular e a sua pureza verificada por eletroforese em gel de poliacrilamida (Filho 2003).

Filho (2003), sugere também que o conhecimento que se tem da extensão da presença de insulina em animais associado aos resultados obtidos sobre a presença de insulina em plantas e cianobactérias e alguns resultados dos que relatam a presença desse hormônio em bactérias e fungos nos levam a crer que essa molécula foi conservada durante a evolução, sugerindo que ela esteja associada aos processos de metabolização de glicose em todos os seres vivos.

\section{Conclusão}

Ao decorrer dos anos o homem codificou a molécula mais importante da vida, 
desenvolver técnicas que modificassem e até mesmo criassem novos organismos, os chamados organismos geneticamente modificados, os quais proporcionaram grande salto para a medicina no tratamento e cura de doenças, sendo uma delas o Diabetes Mellitus (DM), uma doença que vem crescendo de uma maneira preocupante, gerando grande alarde na saúde pública. A maioria das pessoas que possuem DM necessita do uso de insulina constantemente e atualmente graças aos avanços da Engenharia Genética e da padronização e validação dos métodos que compõem a Tecnologia do DNA recombinante, pode-se produzir a mesma artificialmente, trazendo de uma maneira rápida e segura uma nova estratégia terapêutica no tratamento dessa patologia, contribuindo assim para uma melhor qualidade de vida dos pacientes.

\section{Referências Bibliográficas}

CANDEIAS, J. A. N. A Engenharia Genética. Rev. Saúde Pública. São Paulo, vol. 25, n. 1, Fev. 1991.

COELHO, M. A. dos S. Insulina lispro, um produto da biotecnologia. Biotecnologia Ciência \& Desenvolvimento, ano 1, n. 1, Mai. 1997.

CZEPIELEWSKY, M. A. Diabetes Mellitus (DM). ABC da saúde e prevenção. Data de publicação: 01 Nov. 2006. Disponível em: <http://www.abcdasaude.com.br>.
DANIELL, H. Insulina produzida em alface geneticamente modificada. Biotecnologia na saúde. Data de publicação: 09 Ago. 2007.

DIB, S. A. Posição de consenso da Sociedade Brasileira de Diabetes - Insulinoterapia Intensiva com bombas de insulina. Arquivos Brasileiros de Endocrinologia \& Metabologia. São Paulo, vol. 50, n. 1, Fev. 2006.

FERRAZ, A. I.; RODRIGUES, A. S.

Introdução à biotecnologia. Portugal, ano 1, s1. 2007

FILHO, S. A. Insulina de plantas.

Biotecnologia Ciência \& Desenvolvimento, 2003.

FRANCIONI, F. F.; SILVA, D. G. O processo de viver saudável de pessoas com Diabetes Mellitus através de um grupo de convivência. Rev. Saúde Pública.

Florianópolis, vol. 16, n. 1, Jan./Mar. 2007.

LEHNINGER, A. L. Princípios de

Bioquímica. 5ed. São Paulo: Sarvier, 2011.

LIMA, B. D. A produção de insulina humana por Engenharia Genética. Biotecnologia

Ciência \& Desenvolvimento, n. 23, Nov./Dez. 2001.

NARDI, N. B. Terapia Gênica. Rev. Ciência \& Saúde Coletiva. Rio de Janeiro, vol. 7, n. $1,2002$.

RECH, E. Dos vegetais emerge uma nova fonte de substâncias terapêuticas. Biotech. São Paulo, ano 2, n. 1, Fev. 2004.

RECH, E. A biotecnologia e o futuro da medicina. II Especial Biotecnologia. São Paulo, 2004.

RODRIGUES, V. MARTINEZ-ROSSI, NM et al. Tecnologia do DNA recombinante. Faculdade de Medicina de Ribeirão Preto USP. Ribeirão Preto, 2003.

ROSA, R. dos S. Internações por Diabetes Mellitus como diagnóstico principal na rede 
pública do Brasil, 1999 - 2001. Rev.

Brasileira de Epidemiologia. São Paulo, vol. 10, n. 4, Dez. 2007.

ZAHA, A. Biologia Molecular Básica. 3. ed.

Porto Alegre: Mercado Aberto, 2003. 